\title{
Analysis of Ambient Air Quality Conditions of TSP Parameters and Its Source in Temon District
}

\author{
Tozan Ajie Ronowijoyo*, Muhammad Arief Budiharjo, Sri Sumiyati \\ Department of Environmental Engineering, Diponegoro University, Semarang, Indonesia
}

\begin{abstract}
Air pollution as dust particles (TSP) is produced by nature or human activities. Some human activities that produce TSP include transportation and industrial activities. High TSP concentrations can cause disturbances ranging from visual disturbances to health problems. Temon District, Kulon Progo Regency, Yogyakarta Special Region Province is the location of Yogyakarta International Airport, so it is necessary to know the current ambient air quality, especially TSP and its source. This article shows the level of TSP concentration in the Temon District area and its sources. The analysis is done by linking the concentration of the TSP to the traffic volume and road condition. In Temon District, the level of TSP concentration ranges from $22-70.2 \mu \mathrm{g} / \mathrm{m}^{3}$. Traffic volume ranges from 1,720 - 2,099 passenger car unit (pcu)/hour in intersection and 19.51 $565.79 \mathrm{pcu} /$ hour in the roads section. Road conditions start from very bad to good. In general, TSP parameters are still in good condition and do not cause health problems. Primary pollutant sources come from traffic and secondary pollutant sources come from road conditions
\end{abstract}

Keywords. TSP, Traffic, road condition, Temon District.

\section{Introduction}

One of the air pollutants that contributes to the quality of the environment is dust particles or commonly referred to as TSP (Total Suspended Particulate). These pollutants can arise naturally or due to human activities. Human activities that affect the concentration of TSP are traffic volume [1, 2], vehicle speed [3] and industrial activity [4]. While natural conditions in the form of wind conditions [4], soil conditions [5], and road conditions [6], [7].

TSP is a dust particulate that has an aerodynamic diameter of less than $50 \mu \mathrm{m}$ [8] or less than $30 \mu \mathrm{m}$ [9]. A diameter larger than that cannot enter the respiratory tract [8]. TSP also contains smaller particulates, those with an aerodynamic diameter of less than $10 \mu \mathrm{m}$ called

\footnotetext{
*Corresponding Author: iryne.adler@gmail.com, tozanajie@students.undip.ac.id
} 
$\mathrm{PM}_{10}$ and particulates with an aerodynamic diameter of less than $2.5 \mu \mathrm{m}$ called $\mathrm{PM}_{2.5}$. Particulates with a size of $\geq 2.5 \mu \mathrm{m}$ are also referred to as coarse particulate, while particulates with a size of $\leq 2.5 \mu \mathrm{m}$ are called fine particulates [10-12].

Increased concentrations of TSP can cause impacts on humans in the such as visibility disturbances [12], comfort disturbances [13], to health problems [13-16]. The impact of visual disturbances occurs because sunlight is absorbed by airborne particulates [12]. The impact of comfort disturbances occurs due to dust that sticks to the floor and pollutes the environment [13]. While the impact of health problems can be cardiovascular problems such as hypertension $[14,15]$, and cause respiratory problems $[13,16]$.

Dust emissions depend to wind speed that carry the particulates. This displacement can occur due to several processes, such as: dust elevating by aerodynamics, the release of dust and particles due to collision between dust and soil [17] and the release of brake lining particles during braking [18].

On road, the dust is produced both from contact between the tires and the road surface and also due to turbulence generated when the vehicle is moving [6]. The movement of tires on the ground surface will break the crust and aggregate on the surface so that it produces dust emissions [1]. In addition, turbulence generated when a vehicle is moving will be greater along with the greater size of the vehicle [7]. Emissions from braking only occur during braking. Emissions generated depend on the initial speed of the vehicle. The faster the vehicle speed, the greater the emissions [3].

Temon District Kulon Progo Regency Yogyakarta Special Region is the location of Yogyakarta International Airport which will replace Adi Sutjipto Airport. Adi Sutjipto Airport is already impossible to develop due to limited area and natural constraints [19]. TSP is an important parameter in ambient air quality because at certain levels it can cause disturbances ranging from comfort disturbances in the form of visual disturbances to respiratory disorders [13].

This article discusses the ambient air quality conditions of the TSP parameters in Temon District and its main source.

\section{Material and Methods}

The data that used in this article are ambient air quality, road damage conditions and traffic volume in the study area. The interrelation between environmental quality data was analyzed descriptively, so that it can be seen that the environmental factors that most influence the ambient air quality conditions in the study area.

The TSP concentration was converted to an Air Pollution Standard Index based on Decree of Head of Environmental Impact Control Agency (Bapedal) number KEP107/KABAPEDAL/11/1997 regarding Technical Guidelines for Calculation and Reporting and Information on Air Pollution Standards Index (ISPU). The ISPU level is calculated based on the following formula:

$$
I=\frac{I_{a}-I_{b}}{X_{a}-X_{b}}\left(X_{x}-X_{b}\right)+I_{b}
$$

Where:

$\mathrm{I}=$ Calculated of ISPU

$\mathrm{Ia}=$ Top limit of ISPU

$\mathrm{Ib}=$ Bottom limit of ISPU

$\mathrm{Xa}=$ Top limit of ambient concentration

$\mathrm{Xb}=$ Bottom limit of ambient concentration

$\mathrm{Xx}=$ Ambient concentration laboratory analysis 
Limit value of ISPU is presented at 0

Table 1. Limit value of ISPU [13]

\begin{tabular}{|c|c|}
\hline ISPU & $\mathbf{2 4} \mathbf{H}-\mathbf{T S P}\left(\boldsymbol{\mu g} / \mathbf{m}^{\mathbf{3}}\right)$ \\
\hline 50 & 50 \\
\hline 100 & 150 \\
\hline 200 & 350 \\
\hline 300 & 420 \\
\hline 400 & 500 \\
\hline 500 & 600 \\
\hline
\end{tabular}

The ISPU category based on ISPU values is presented in 0

Table 2. The ISPU category and its impact to human and environment [13]

\begin{tabular}{|c|c|l|}
\hline ISPU & CATEGORY & \multicolumn{1}{|c|}{ IMPACT TO THE HUMAN AND ENVIRONMENT } \\
\hline $1-50$ & Good & No effect \\
\hline $51-100$ & Medium & Decreasing the visibility range \\
\hline $101-199$ & Unhealthy & Decreasing the visibility range and dust everywhere \\
\hline $200-299$ & Very unhealthy & Increased sensitivity in patients with asthma and bronchitis \\
\hline$\geq 300$ & Dangerous & Dangerous level for all exposed populations \\
\hline
\end{tabular}

The air quality sampling methods refer to SNI 19-7119.9-2005. The sampling location and the results of the TSP parameters of each location are presented in 0

Table 3. Air quality sampling location [20, 21]

\begin{tabular}{|c|l|c|c|}
\hline CODE & \multicolumn{1}{|c|}{ NAME } & \multicolumn{1}{c|}{ EAST } & SOUTH \\
\hline Q01 & Kulur Village & $110^{\circ} 05^{\prime} 44.64^{\prime \prime}$ & $7^{\circ} 52^{\prime} 45.82^{\prime \prime}$ \\
\hline Q02 & Kaligintung Village & $110^{\circ} 05^{\prime} 40.54^{\prime \prime}$ & $7^{\circ} 52^{\prime} 50.35^{\prime \prime}$ \\
\hline Q03 & Kalidengen Village & $110^{\circ} 05^{\prime} 20.86^{\prime \prime}$ & $7^{\circ} 53^{\prime} 40.33^{\prime \prime}$ \\
\hline Q04 & Kretek, Glagah Village & $110^{\circ} 04^{\prime} 02.20^{\prime \prime}$ & $7^{\circ} 53^{\prime} 58.80^{\prime \prime}$ \\
\hline Q05 & Bebekan, Glagah Village & $110^{\circ} 04^{\prime} 30.85^{\prime \prime}$ & $7^{\circ} 53^{\prime} 53.21^{\prime \prime}$ \\
\hline Q06 & Sindutan B, Sindutan Village & $110^{\circ} 02^{\prime} 34.37^{\prime \prime}$ & $7^{\circ} 53^{\prime} 06.85^{\prime \prime}$ \\
\hline Q07 & Weton, Kebonrejo Village & $110^{\circ} 03^{\prime} 50.77^{\prime \prime}$ & $7^{\circ} 53^{\prime} 10.39^{\prime \prime}$ \\
\hline Q08 & Munggangan, Palihan Village & $110^{\circ} 03^{\prime} 35.65^{\prime \prime}$ & $7^{\circ} 53^{\prime} 48.56^{\prime \prime}$ \\
\hline Q09 & Bebekan, Glagah Village & $110^{\circ} 04^{\prime} 22.24^{\prime \prime}$ & $7^{\circ} 54^{\prime} 10.77^{\prime \prime}$ \\
\hline Q10 & Karang Wuni, Karangwuni Village & $110^{\circ} 05^{\prime} 26.81^{\prime \prime}$ & $7^{\circ} 54^{\prime} 42.27^{\prime \prime}$ \\
\hline Q11 & Jangkaran, Jangkaran Village & $110^{\circ} 02^{\prime} 07.73^{\prime \prime}$ & $7^{\circ} 53^{\prime} 45.80^{\prime \prime}$ \\
\hline
\end{tabular}

The location of roads condition measurement is presented at 0 and 0 
Table 4. Roads damage sampling location [20]

\begin{tabular}{|c|l|c|c|}
\hline NO. & \multicolumn{1}{|c|}{ NAME } & $\begin{array}{c}\text { START } \\
\text { COORDINATE }\end{array}$ & $\begin{array}{c}\text { END } \\
\text { COORDINATE }\end{array}$ \\
\hline 1. & $\begin{array}{l}\text { Wates - Purworejo road } \\
\text { (Temon District - Glagah beach intersection) }\end{array}$ & $\begin{array}{c}110^{\circ} 04^{\prime} 38.8^{\prime \prime} \mathrm{E} \\
7^{\circ} 53^{\prime} 12.9^{\prime \prime} \mathrm{S}\end{array}$ & $\begin{array}{c}110^{\circ} 05^{\prime} 33.3^{\prime \prime} \mathrm{E} \\
7^{\circ} 53^{\prime} 17.0^{\prime \prime} \mathrm{S}\end{array}$ \\
\hline 2. & Kedundang road - Abudini road & $\begin{array}{c}110^{\circ} 05^{\prime} 30.7^{\prime \prime} \mathrm{E} \\
7^{\circ} 53^{\prime} 16.3^{\prime \prime} \mathrm{S}\end{array}$ & $\begin{array}{c}110^{\circ} 05^{\prime} 44.9^{\prime \prime} \mathrm{E} \\
7^{\circ} 52^{\prime} 46.3^{\prime \prime} \mathrm{S}\end{array}$ \\
\hline 3. & Kedundang road - Kaligintung Village & $\begin{array}{c}110^{\circ} 05^{\prime} 43.6^{\prime \prime} \mathrm{E} \\
7^{\circ} 52^{\prime} 52.0^{\prime \prime} \mathrm{S}\end{array}$ & $\begin{array}{c}110^{\circ} 05^{\prime} 34.2^{\prime \prime} \mathrm{E} \\
7^{\circ} 52^{\prime} 48.7^{\prime \prime} \mathrm{S}\end{array}$ \\
\hline 4. & Glagah Beach road (Temon District) - & $\begin{array}{c}110^{\circ} 04^{\prime} 38.8^{\prime \prime} \mathrm{E} \\
7^{\circ} 53^{\prime} 12.9^{\prime \prime} \mathrm{S}\end{array}$ & $\begin{array}{c}110^{\circ} 04^{\prime} 22.0^{\prime \prime} \mathrm{E} \\
7^{\circ} 54^{\prime} 10.1^{\prime \prime} \mathrm{S}\end{array}$ \\
\hline 5. & Daendels Pantai Selatan road & $\begin{array}{c}110^{\circ} 05^{\prime} 33.3^{\prime \prime} \mathrm{E} \\
7^{\circ} 53^{\prime} 17.0^{\prime \prime} \mathrm{S}\end{array}$ & $\begin{array}{c}110^{\circ} 04^{\prime} 59.0^{\prime \prime} \mathrm{E} \\
7^{\circ} 54^{\prime} 28.6^{\prime \prime} \mathrm{S}\end{array}$ \\
\hline
\end{tabular}

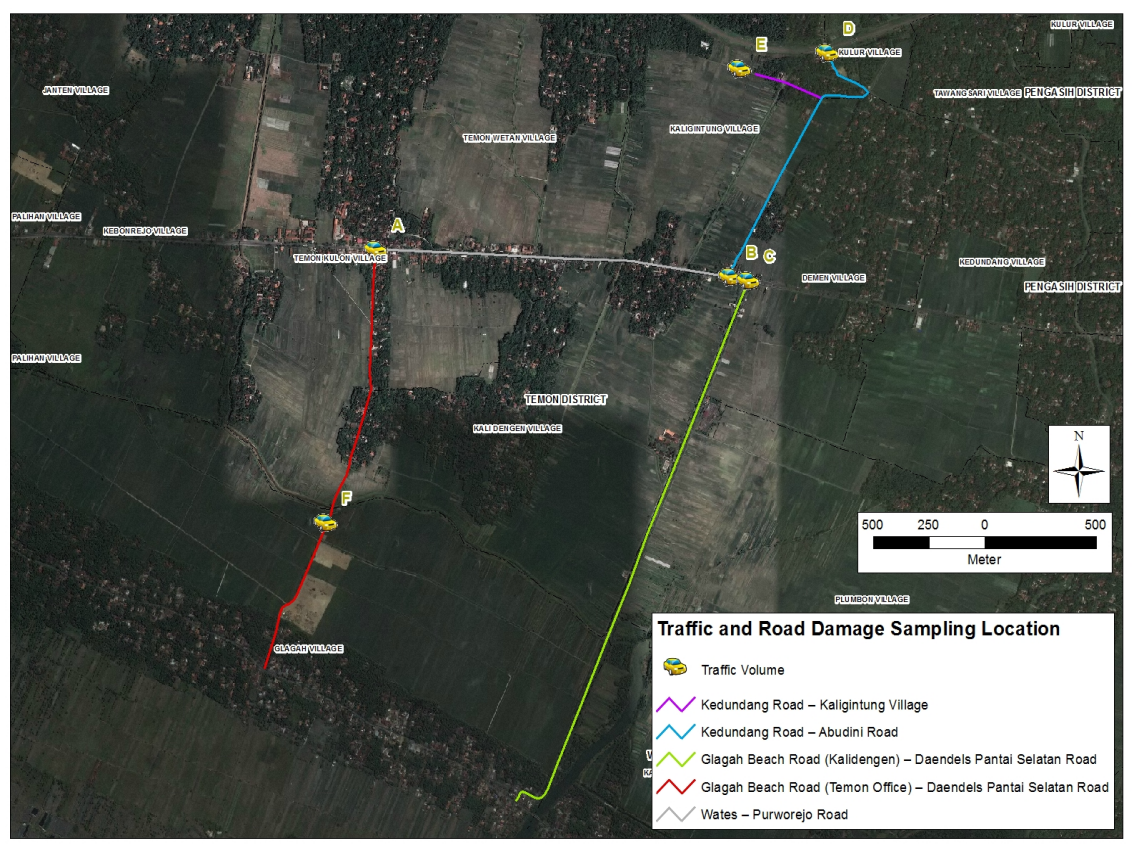

Fig. 1. Map of road damage and traffic volume sampling location

Determination of road conditions refer to the road condition survey guidelines No. SMD-03 / RCS. SDI values are determined by 3 main types of damage such as: potholes, rutting and cracking. Determination of the SDI value is carried out as follows [22]:

1. SDI based on crack area category (stated as SDI-1)

a. Crack area $<10 \%$ of road area, then SDI1 $=5$

b. Crack area between $10 \%-30 \%$, then SDI $1=20$

c. Crack area $>30 \%$, then SDI $1=40$

2. SDI based on width of crack category (stated as SDI-2)

a. Width of crack less than $3 \mathrm{~mm}$, then SDI2 = SDI1

b. Width of crack larger than $3 \mathrm{~mm}$, then SDI $2=\mathrm{SDI} 1 * 2$ 
3. SDI based on amount of potholes per km (stated as SDI-3)

a. Amount of potholes $<10$ per $\mathrm{km}$, then SDI3 $=\mathrm{SDI} 2+15$

b. Amount of potholes between $10-50$ per $\mathrm{km}$, then SDI3 $=\mathrm{SDI} 2+75$

c. Amount of potholes $>50$ per km, then SDI3 $=$ SDI $2+225$

4. SDI based on average depth of rut $(\mathrm{cm})$ (stated as SDI-4)

a. Depth of rut $<1 \mathrm{~cm}$, determinate by $\mathrm{X}=0,5$ then value of SDI4 $=\mathrm{SDI} 3+5 * \mathrm{X}$

b. Depth of rut between $1-3 \mathrm{~cm}$, determinate by $\mathrm{X}=2$ then value of SDI $4=\mathrm{SDI} 3+$ $5 * X$

c. Depth of rut $>3 \mathrm{~cm}$, determinate by $\mathrm{X}=5$ then value of SDI $4=\mathrm{SDI} 3+20$

5. SDI-4 value is the total value of SDI parameter which is a composite value of 3 types of road damage along with its severity.

The location of traffic survey presented on 0

Table 5. Location of traffic volume sampling [20, 21]

\begin{tabular}{|c|l|c|c|}
\hline LOCATION & \multicolumn{1}{|c|}{ NAME } & EAST & SOUTH \\
\hline A & $\begin{array}{l}\text { Uncontrolled three way intersection of Temon } \\
\text { District - Glagah Beach road }\end{array}$ & $110^{\circ} 04^{\prime} 38.8^{\prime \prime}$ & $7^{\circ} 53^{\prime} 12.9^{\prime \prime}$ \\
\hline B & $\begin{array}{l}\text { Uncontrolled three way intersection of Kedundang } \\
\text { road - Wates Purworejo road }\end{array}$ & $110^{\circ} 05^{\prime} 30.7^{\prime \prime}$ & $7^{\circ} 53^{\prime} 16.3^{\prime \prime}$ \\
\hline C & $\begin{array}{l}\text { Uncontrolled three way intersection of Glagah } \\
\text { Beach road - Wates Purworejo road }\end{array}$ & $110^{\circ} 05^{\prime} 33.3^{\prime \prime}$ & $7^{\circ} 53^{\prime} 17.0^{\prime \prime}$ \\
\hline D & Abudini road & $110^{\circ} 05^{\prime} 44.9^{\prime \prime}$ & $7^{\circ} 52^{\prime} 46.3^{\prime \prime}$ \\
\hline E & Kaligintung Village road & $110^{\circ} 05^{\prime} 34.2^{\prime \prime}$ & $7^{\circ} 52^{\prime} 48.7^{\prime \prime}$ \\
\hline F & Glagah Beach road & $110^{\circ} 04^{\prime} 38.8^{\prime \prime}$ & $7^{\circ} 53^{\prime} 12.9^{\prime \prime}$ \\
\hline
\end{tabular}

All of intersections are uncontrolled three way intersections. Performance analysis of the intersections and road section using the Indonesian Road Capacity Manual (MKJI, 1997) for uncontrolled intersection modules and road segments modules [23].

Error! Reference source not found. showed the location of traffic survey as described in 0

\section{Result and Discussion}

\subsection{Ambient Air Quality Result}

The ambient air quality data was obtained from an EIA study that conducted in the Temon District area. They are the EIA Study of the Construction of the New Yogyakarta International Airport and the EIA study of Railway Construction between the Kedundang Station and the New Yogyakarta International Airport Station.

Ambient air quality data of TSP parameters and its conversion into ISPU categories are presented in 0 
Table 6. Concentration of TSP and its ISPU category [20, 21]

\begin{tabular}{|c|l|c|c|}
\hline \multirow{2}{*}{ LOCATION } & \multicolumn{1}{|c|}{ NAME } & $\begin{array}{c}\text { TSP } \\
\text { CONSENTRATION } \\
\left(\boldsymbol{\mu g} / \mathbf{m}^{3}\right)\end{array}$ & $\begin{array}{c}\text { ISPU } \\
\text { CATEGORY }\end{array}$ \\
\hline Q01 & Kulur Village & 32 & Good \\
\hline Q02 & Kaligintung Village & 37 & Good \\
\hline Q03 & Kalidengen Village & 22 & Good \\
\hline Q04 & Kretek, Glagah Village & 43 & Good \\
\hline Q05 & Bebekan, Glagah Village & 52 & Medium \\
\hline Q06 & Sindutan B, Sindutan Village & 70.2 & Medium \\
\hline Q07 & Weton, Kebonrejo Village & 62.88 & Medium \\
\hline Q08 & Munggangan, Palihan Village & 58.21 & Medium \\
\hline Q09 & Bebekan, Glagah Village & 57.19 & Medium \\
\hline Q10 & Karang Wuni, Karangwuni Village & 54.11 & Medium \\
\hline Q11 & Jangkaran, JangkaranVillage & 51.67 & \\
\hline
\end{tabular}

0 shows that the TSP concentration conditions between $22-70.2 \mu \mathrm{g} / \mathrm{m}^{3}$. Most of the locations are in the "Medium" category and others are in "Good" condition.

0 shows the distribution of sampling locations based on ISPU Index categories and its position by road.

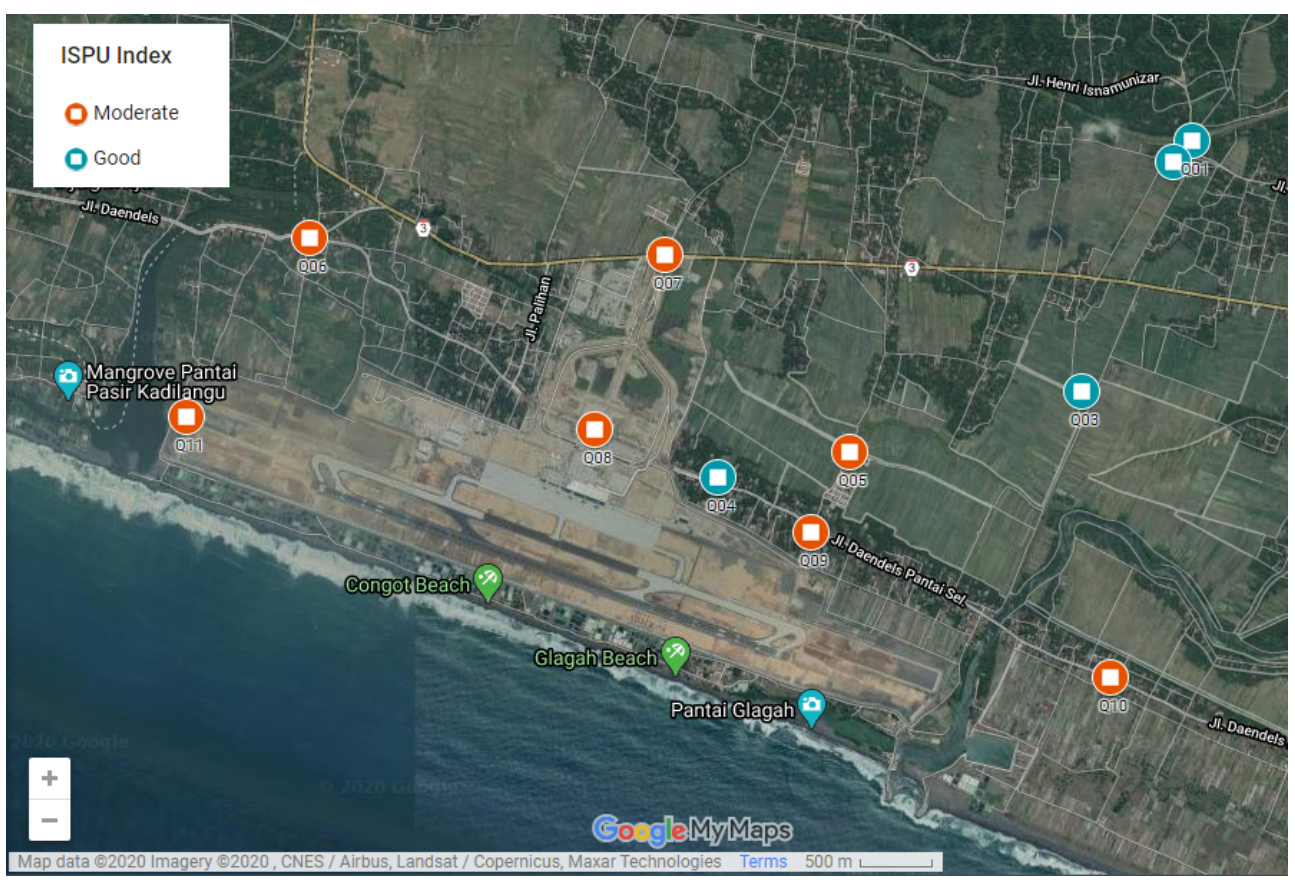

Fig. 2. Map of distribution of sampling location based on ISPU category 
Location Q07 is close to National Road IV, which connects Wates District and Purworejo Regency. Locations Q04, Q06, Q08, Q09 and Q10 are close to Daendels Street. While locations Q01, Q02, Q03, Q05 and Q11 are close to local roads that connect between villages or within villages

\subsection{Traffic Volume Result}

The traffic conditions were obtained from an EIA study of the railway construction between Kedundang Station - New Yogyakarta International Airport Station at Temon District. The survey of traffic are conducted at holiday and workday for each location survey. The traffic volume result at intersection location are presented in 0

Table 7. Traffic condition at intersection [20]

\begin{tabular}{|l|l|c|c|c|c|}
\hline \multicolumn{1}{|c|}{ INTERSECTION } & TIME & $\begin{array}{c}\text { TRAFFIC } \\
\text { VOLUME } \\
\text { (pcu/h) }\end{array}$ & $\begin{array}{c}\text { DEGREE OF } \\
\text { SATURATION } \\
\text { (DS) }\end{array}$ & $\begin{array}{c}\text { DELAY } \\
\text { (s/vehicle) }\end{array}$ & $\begin{array}{c}\text { LEVEL of } \\
\text { SERVICE }\end{array}$ \\
\hline $\begin{array}{l}\text { Intersection of Temon District } \\
\text { Glagah Beach road (A) }\end{array}$ & Workday & 1,958 & 0.57 & 9.47 & $\mathrm{~B}$ \\
\cline { 2 - 6 } & Holiday & 1,772 & 0.64 & 10.23 & $\mathrm{~B}$ \\
\hline $\begin{array}{l}\text { Intersection of Kedundang road } \\
(\mathrm{B})\end{array}$ & Workday & 1,902 & 0.54 & 9.13 & $\mathrm{~B}$ \\
\cline { 2 - 7 } & Holiday & 1,720 & 0.57 & 9.40 & $\mathrm{~B}$ \\
\hline $\begin{array}{l}\text { Intersection of Glagah Beach } \\
\text { road (C) }\end{array}$ & Workday & 2,099 & 0.49 & 8.70 & $\mathrm{~B}$ \\
\cline { 2 - 6 } & Holiday & 1,725 & 0.59 & 9.72 & $\mathrm{~B}$ \\
\hline
\end{tabular}

Regulation of Minister of Public Works No. 19/PRT/M/2011 determines the maximum of DS value is 0.85 . This regulation does not set limits for delay value, but the higher the DS value then the delay value will be higher too. Thus, if the DS value still meets the requirements, then the delay is considered meets the requirements as well.

Minister of Transportation Regulation No. KM 14 of 2006 states that there are grouping levels of services at intersection based on the delay value. The average maximum delay that is feasible (or at service level C) for uncontrolled intersections is expected to be no more than $20 \mathrm{~s} / \mathrm{veh}$.

0 shows that the every location of observed intersection still meets the requirements, both in DS (based on PM No. 19 / PRT / M / 2011), and delays (based on KM No 14/2006).

The traffic survey result at road sections are presented at 0

Table 8. Traffic condition at road section [20]

\begin{tabular}{|l|c|c|c|c|c|}
\hline \multirow{2}{*}{ ROAD SECTION } & TIME & $\begin{array}{c}\text { PEAK } \\
\text { HOUR }\end{array}$ & $\begin{array}{c}\text { TRAFFIC } \\
\text { VOLUME } \\
\text { (pcu/h) }\end{array}$ & $\begin{array}{c}\text { DEGREE OF } \\
\text { SATURATION } \\
\text { (DS) }\end{array}$ & $\begin{array}{c}\text { LEVEL OF } \\
\text { SERVICES }\end{array}$ \\
\hline \multirow{2}{*}{ Abudini road (D) } & Workday & $06.15-07.15$ & 565.79 & 0.29 & $\mathrm{~A}$ \\
\cline { 2 - 6 } & Holiday & $16.00-17.00$ & 507.26 & 0.26 & $\mathrm{~A}$ \\
\hline \multirow{2}{*}{$\begin{array}{l}\text { Kaligintung Village road } \\
\text { (E) }\end{array}$} & Workday & $11.00-12.00$ & 40.26 & 0.02 & $\mathrm{~A}$ \\
\cline { 2 - 6 } & Holiday & $16.00-17.00$ & 19.51 & 0.01 & $\mathrm{~A}$ \\
\hline \multirow{2}{*}{ Glagah Beach road (F) } & Workday & $06.30-07.30$ & 342.21 & 0.17 & $\mathrm{~A}$ \\
\cline { 2 - 6 } & Holiday & $16.00-17.00$ & 292.65 & 0.15 & $\mathrm{~A}$ \\
\hline
\end{tabular}


The level of service in category A in every road section. There are free flow and average travel speed might be higher than $80 \mathrm{~km} / \mathrm{h}$. So, the driver has sufficient freedom to choose the speed. Refer to the Minister of Public Works Regulation No. 19/PRT/M/2011, the required DS value is a maximum of 0.85 for primary and collector roads. So that, every observed road section is still within the permitted limits.

\subsection{Road Condition}

The road conditions data were obtained from an EIA study of the Railway Construction between Kedundang Station - New Yogyakarta International Airport Station.

The results of observing road conditions for each road section are presented in 0

Table 9. Road damage condition [20]

\begin{tabular}{|l|c|c|c|c|}
\hline \multicolumn{1}{|c|}{ ROAD SECTION } & $\begin{array}{c}\text { GOOD } \\
\mathbf{( 0 - 5 0 )}\end{array}$ & $\begin{array}{c}\text { LIGHT } \\
\text { DAMAGED } \\
\mathbf{( 5 0 - 1 0 0 )}\end{array}$ & $\begin{array}{c}\text { MEDIUM } \\
\text { DAMAGED } \\
\mathbf{( 1 0 0 - 1 5 0 )}\end{array}$ & $\begin{array}{c}\text { HEAVY } \\
\text { DAMAGED } \\
\text { (> 150) }\end{array}$ \\
\hline $\begin{array}{l}\text { From Wates - Purworejo Road } \\
\text { To Glagah Beach road }\end{array}$ & $66.67 \%$ & $26.67 \%$ & 0 & $6.67 \%$ \\
\hline $\begin{array}{l}\text { From Glagah Beach road - } \\
\text { To Wates - Purworejo road }\end{array}$ & $85.71 \%$ & $14.29 \%$ & 0 & 0 \\
\hline $\begin{array}{l}\text { From Kedundang road } \\
\text { To Abudini road }\end{array}$ & $50 \%$ & $50 \%$ & 0 & 0 \\
\hline $\begin{array}{l}\text { From Abudini road } \\
\text { To Kedundang road }\end{array}$ & $50 \%$ & $25 \%$ & $16.67 \%$ & $8.33 \%$ \\
\hline $\begin{array}{l}\text { From Kedundang road } \\
\text { To Kaligintung Village road }\end{array}$ & 0 & $62.5 \%$ & 0 & $100 \%$ \\
\hline $\begin{array}{l}\text { From Kaligintung road } \\
\text { To Kedundang road }\end{array}$ & $21.43 \%$ & $21.43 \%$ & $50 \%$ & $7.14 \%$ \\
\hline $\begin{array}{l}\text { From Glagah Beach road } \\
\text { To Daendels Pantai Selatan road }\end{array}$ & $25 \%$ & $18.75 \%$ & $12.5 \%$ & $43.75 \%$ \\
\hline $\begin{array}{l}\text { From Daendels Pantai Selatan road } \\
\text { To Glagah Beach road }\end{array}$ & $66.67 \%$ & $14.29 \%$ & 0 & $19.05 \%$ \\
\hline $\begin{array}{l}\text { From Glagah Beach road (Kalidengen } \\
\text { Village) } \\
\text { To Daendels Pantai Selatan road }\end{array}$ & $50 \%$ & $22.73 \%$ & $22.73 \%$ & $4.55 \%$ \\
\hline $\begin{array}{l}\text { From Daendels Pantai Selatan road } \\
\text { To Glagah Beach road (Kalidengen Village) }\end{array}$ & 0 & 0 & 0 \\
\hline
\end{tabular}

The observation results show that, most of the damage are fatigue cracks. This shows that the truck load has caused plastic deformation on the pavement, and the aging process of asphalt causes the pavement surface to be prone to crack. Some of crack that have been repaired with a thin layer of asphalt mixture seen to be cracked again due to the crack propagation from the underlying layers. 


\subsection{Discussion}

The level of TSP concentration in all observation locations still meets ambient air quality standards based on the DIY Governor Regulation. However, when linked to the observation location, the TSP level at locations around the National road (location Q06) and Daendels south coast road are higher (locations Q07, Q08, Q09, and Q10) than sampling locations that are not around the roads (location Q01, Q02, Q03). This shows that the contribution of traffic conditions is quite high. This is analyses is strengthened by traffic data on the three intersections on the national road which ranges from 1,720 to $2,099 \mathrm{pcu} / \mathrm{h}$.

However, at the Q04 that around the Daendels Pantai Selatan road, the TSP concentration was relatively low although it remained higher compared to locations that were not around the main road. This is because, sampling is carried out when the Daendels Pantai Selatan road is closed for airport construction purposes. So that traffic is very low.

Different conditions occur at the Q05 location, which is not on a main road but has a higher concentration value than at other non-main road locations. Referring to the road condition data, the roads around the Q05 location are in pretty bad condition. It is heavy damaged condition by $43 \%$ for the direction from Daendels Pantai Selatan road to Wates Purworejo road (National Road IV) and 19\% heavy damaged condition for the opposite direction. Then, the traffic conditions on working days are $342.21 \mathrm{pcu} / \mathrm{h}$. Its indicated, there is contribution of road and traffic conditions to the TSP concentration at this location.

The Q02 location, which was also in a very bad condition (100\% heavily damaged) but the TSP concentration level was relatively low. This is because the traffic condition is very small. The traffic volume is $40.26 \mathrm{pcu} /$ hour during workday. This shows that the biggest contribution of TSP concentration is traffic. In addition, road conditions also contribute but not as much as traffic conditions.

The source of TSP emissions due to traffic comes from combustion gases, brake particles released during braking, particles released from tires and suspended road dust [18, 24]. Most of the dust emission comes from road dust, and only a maximum of $5 \%$ comes from the release of tire particles due to road tire friction [18]. While the emission from the released brake pad particles only occurs when braking and depend of vehicle starting speed $[3]$.

The factors that affecting the level of suspended dust are regional conditions, weather, traffic speed and traffic volume. Traffic speed has a correlation with traffic volume. If traffic speed is not a consideration, then the traffic volume has a significant effect on TSP emissions [2].

There are no industrial activities that have the potential to contribute to the level of TSP concentration at Temon District. So that it can be determinated that the source of the TSP concentration only comes from traffic activities and road conditions.

The ISPU index shows that the condition of the TSP is in good to moderate condition. Moderate category level results in disturbances of visibility. The concentration level is between 51 and $70 \mu \mathrm{g} / \mathrm{m}^{3}$. In China, a TSP concentration level of $75 \mu \mathrm{g} / \mathrm{m}^{3}$ could disturbed the visibility [12]. In addition, the concentration range of $51-70 \mu \mathrm{g} / \mathrm{m}^{3}$ does not cause cardiovascular disorders. Cardiovascular disorders such as hypertension will occur when exposed to concentrations of $164 \mu \mathrm{g} / \mathrm{m}^{3}$ for 2 hours [15].

\section{Conclusion}

The level of TSP concentration in Temon District is influenced by two things, there are traffic and road conditions. The biggest influence is traffic then the next are road conditions. This level of TSP concentration does not cause health problems but will cause disturbances of visibility. 


\section{Acknowledgement}

This article was supported by Department of Environmental Engineering, Faculty of Engineering Diponegoro University.

\section{References}

1. K. W. Nicholson, J. R. Branson, P. Giess, and R. J. Cannel, "The Effect Of Vehicle Activity On Particle Resuspension," J. Aerosol Sci., vol. 20, no. 8, pp. 1425-1428, (1989).

2. V. Etyemezian et al., "Vehicle-based road dust emission measurement (III): Effect of speed, traffic volume, location, and season on PM10 road dust emissions in the Treasure Valley, ID," Atmos. Environ., vol. 37, no. 32, pp. 4583-4593, (2003), doi: 10.1016/S1352-2310(03)00530-2.

3. L. Chasapidis, T. Grigoratos, A. Zygogianni, A. Tsakis, and A. G. Konstandopoulos, "Study of Brake Wear Particle Emissions of a Minivan on a Chassis Dynamometer," Emiss. Control Sci. Technol., vol. 4, no. 4, pp. 271-278, (2018), doi: 10.1007/s40825018-0105-7.

4. A. G. Simandjuntak, "Pencemaran Udara," Buletin Limbah, vol. 11, no. 1, pp. 34-40, (2007).

5. A. S. Yuwono, B. Mulyanto, M. Fauzan, F. Mulyani, and C. R. Munthe, "Generation of Total Suspended Particulate (TSP) in Ambient Air from Four Soil Types in Indonesia," Int. J. Appl. Environ. Sci., vol. 11, no. 4, pp. 995-1006, (2016), [Online]. Available: http://www.ripublication.com.

6. D. S. Williams, M. K. Shukla, and J. Ross, "Particulate matter emission by a vehicle running on unpaved road," Atmos. Environ., vol. 42, no. 16, pp. 3899-3905, (2008), doi: 10.1016/j.atmosenv.2008.02.003.

7. J. A. Gillies, V. Etyemezian, H. Kuhns, D. Nikolic, and D. A. Gillette, "Effect of vehicle characteristics on unpaved road dust emissions," Atmos. Environ., vol. 39, no. 13, pp. 2341-2347, (2005), doi: 10.1016/j.atmosenv.2004.05.064.

8. I. P. S. Araújo, D. B. Costa, and R. J. B. de Moraes, "Identification and characterization of particulate matter concentrations at construction jobsites," Sustain., vol. 6, no. 11, pp. 7666-7688, (2014), doi: 10.3390/su6117666.

9. US-EPA, “AP-42: Section 13.2.1 Paved Roads," (2016), [Online]. Available: https://www3.epa.gov/ttnchie1/ap42/ch13/final/c13s0201.pdf.

10. J. D. Joksić et al., "Physical And Chemical Characterization of The Particulate Matter Suspended In Aerosols From The Urban Area of Belgrade," J. Serbian Chem. Soc., vol. 74, no. 11, pp. 1319-1333, (2009), doi: 10.2298/JSC0911319J.

11. G. C. Fang, C. N. Chang, Y. S. Wu, P. P. C. Fu, K. F. Chang, and D. G. Yang, "The characteristic study of TSP, PM(2.5 10) and PM2.5 in the rural site of central Taiwan," Sci. Total Environ., vol. 232, no. 3, pp. 177-184, (1999), doi: 10.1016/S00489697(99)00092-3.

12. Y. Liu, T. Zhang, Q. Liu, R. Zhang, Z. Sun, and M. Zhang, "Seasonal Variation of Physical and Chemical Properties in TSP, PM10 and PM2.5 at a Roadside Site in Beijing and Their Influence on Atmospheric Visibility," Aerosol Air Qual. Res., vol. 14, pp. 954-969, (2014), doi: 10.4209/aaqr.2013.01.0023.

13. Bapedal, "Keputusan Kepala Bapedal Nomor KEP-107/KABAPEDAL/11/1997 tentang Perhitungan dan Pelaporan Serta Informasi Indeks Standar Pencemar Udara," Jakarta, (1997). doi: 10.1017/CBO9781107415324.004. 
14. H. C. Yang, S. H. Chang, R. Lu, and D. M. Liou, "The effect of particulate matter size on cardiovascular health in Taipei Basin, Taiwan," Comput. Methods Programs Biomed., vol. 137, no. 155, pp. 261-268, (2016), doi: 10.1016/j.cmpb.2016.08.014.

15. J. B. Byrd et al., "Acute increase in blood pressure during inhalation of coarse particulate matter air pollution from an urban location," J. Am. Soc. Hypertens., vol. 10, no. 2, pp. 133-139.e4, (2016), doi: 10.1016/j.jash.2015.11.015.

16. F. Khairunnisa, H. S. Huboyo, and T. Istirokhatun, "Analisis Komposisi Unsur Pencemar ( $\mathrm{Si}, \mathrm{Pb}$, Dan Ca) Dalam Total Suspended Particulate (TSP) Di Pembangunan Jalan (Studi Kasus: Pembangunan Jalan Kendal - Batas Kota Semarang, Jawa Tengah)," J. Tek. Lingkung., vol. 4, no. 4, pp. 1-11, (2015).

17. G. Yulevitch et al., "Evaluation of wind-induced dust-PM emission from unpaved roads varying in silt content by experimental results," Atmos. Pollut. Res., no. October, pp. 1-8, (2019), doi: 10.1016/j.apr.2019.10.010.

18. K. J. Kupiainen, H. Tervahattu, M. Räisänen, T. Mäkelä, M. Aurela, and R. Hillamo, "Size and composition of airborne particles from pavement wear, tires, and traction sanding," Environ. Sci. Technol., vol. 39, no. 3, pp. 699-706, (2005), doi: 10.1021/es035419e.

19. G. Ramdhani, "Deretan Alasan Kuat Yogyakarta Harus Segera Punya Bandara Baru," Liputan6.com, (2018). https://www.liputan6.com/news/read/3241278/deretan-alasankuat-yogyakarta-harus-segera-punya-bandara-baru (accessed Feb. 19, 2020).

20. Balai Teknik Perkeretaapian Kelas I Wilayah Jawa Bagian Tengah, Analisis Dampak Lingkungan Rencana Pembangunan Jalur Kereta Api Umum Nasional Lintas Stasiun Kedundang - Stasiun Bandar Udara Yogyakarta Baru di Kabupaten Kulon Progo. Semarang: Balai Teknik Perkeretaapian Kelas I Wilayah Jawa Bagian Tengah, 2018.

21. PT. Angkasa Pura I (Persero), Analisis Mengenai Dampak Lingkungan Hidup (Amdal) Pembangunan Bandar Udara New Yogyakarta International Airport. Jakarta: PT. Angkasa Pura I (Persero), 2017.

22. B. H. Setiadji, "Proposed SDI equations to improve the effectiveness in evaluating crack damage on the road pavement Proposed SDI equations to improve the effectiveness in evaluating crack damage on the road pavement," First Int. Conf. Constr. Infrastructure, Mater, (2019), doi: 10.1088/1757-899X/650/1/012007.

23. Direktorat Jenderal Bina Marga, Manual Kapasitas Jalan Indonesia, vol. 1, no. I. 1997.

24. W. F. Rogge, L. M. Hildemann, M. A. Mazurek, G. R. Cass, and B. R. T. Simoneit, "Sources of Fine Organic Aerosol. 3. Road Dust, Tire Debris, and Organometallic Brake Lining Dust: Roads as Sources and Sinks," Environ. Sci. Technol., vol. 27, no. 9, pp. 1892-1904, (1993), doi: 10.1021/es00046a019. 